\title{
The Influence of the Teaching Style of Communication on the Motivation of Students to Learn Foreign Languages
}

\author{
Marina Ivanova \\ Moscow State University of Food Production
}

Correspondence concerning this article should be addressed to Marina Ivanova, Moscow State University of Food Production, 11 Volokolamskoe shosse, Moscow, Russian Federation, 115080.E-mail: m.a.iv@mail.ru

\author{
Natalia Shlenskaya \\ Moscow State University of Food Production
}

Correspondence concerning this article should be addressed to Natalia Shlenskaya, Moscow State University of Food Production, 11 Volokolamskoe shosse, Moscow, Russian Federation, 115080. E-mail: teaver@yandex.ru

\author{
Natalia Mekeko \\ Peoples' Friendship University of Russia
}

Correspondence concerning this article should be addressed to Natalia Mekeko, Peoples' Friendship University of Russia, 3 Ordzhonikidze street, Moscow, 115419, Russian Federation.E-mail: nmekeko@yandex.ru

\author{
Tatiana Kashkarova \\ National Research University Higher School of Economics
}

Correspondence concerning this article should be addressed to Tatiana Kashkarova, National Research University Higher School of Economics , Department of English for Economic and Mathematical Studies, 26 Shabolovka St., Moscow, 119049, Russian Federation.E-mail: kashka54@mail.ru

\begin{abstract}
Nowadays, when the role of knowing foreign languages is extremely high and the demand for specialists who are proficient in a language is continuing to increase, we face the problem of a lack of desire to learn foreign languages among non-linguistic majors. We supposed that the type of teacher-student interaction style (authoritarian, democratic, and liberal) could influence students' motivation type (internal, external positive, external negative, or amotivation) and this was the aim of the study. We surveyed 230 second-year students of the intramural form of study seeking a baccalaureate degree from Moscow State University of Food Production. Among the respondents there were 143 girls and 87 boys aged 18-20, citizens of the Russian Federation. The experiment was divided into three stages and it took three semesters to complete the study. The aim of the first stage was to investigate students' preferences related to teacherstudent interaction style, and the prevailing type of learning motivation to study and to learn foreign languages. The second stage of the study was aimed to investigate how teacher-student interaction style influences the nature and type of students' motivation to learn. In the last stage of the study, the output testing of student performance was implemented and all the results from the previous stages were compared and analyzed. The results of the experiment clearly demonstrated that both authoritarian and democratic teacher-student interaction styles could have a positive influence on students' educational behaviour and academic performances while the implementation of the liberal teacher-student interaction style led to amotivation. At the same time, the democratic style, contrary to the authors' hypothesis, predominantly provoked external motivation, while an authoritarian style significantly activated internal motivation.
\end{abstract}

Keywords: teacher-student interaction style, teaching style, motivation, student performance 


\section{Introduction}

In today's era of scientific and technical revolution with the arrival of the internet and the modern means of communications coupled with increased in the migration process and increasing mobility, the boundaries between countries and nations are disappearing. People from different parts of the globe have been interacting more and more often and creating diverse educational, cultural, scientific, economic, political, and business collaborations and relations. In this context, the role of foreign languages in modern society are incredibly huge. In spite of the fact that English acts as a global language, a so-called "lingua franca", functioning both in scientific and intellectual discourse and as a mean of routine communication' (Tikhonova \& Raitskaya, 2018), a wide range of foreign languages are becoming more significant as evidenced by their integration in the everyday usage of modern specialists (Chinese, Spanish, Arabic, etc.). This can easily be explained by the political and industrial development of several regions around the globe.

According to the French linguist F. Debyser (1983), "an educated person of the XXI century must speak fluently at least two languages of the world where the distance between countries has shortened but the language barriers have not been broken". However, currently being proficient in a foreign language is not just an additional element of the common culture of an educated person, it is a hard necessity. The demand for specialists who are proficient in a foreign language has also been increasing from year to year. Foreign language communicative competence is becoming one of the most important selection criterions in employment and a key factor for career development. Thus, in the current social and economic situation, the learning of foreign languages pursues command of that language as a mean of intercultural communication for the achievement of social and domestic as well as educational and professional demands. However, in spite of the heightened necessity of foreign language communicative competence and the great demand for specialists knowing foreign languages, non-linguistic university students worldwide take little interest in foreign language learning.

There are several reasons explaining the current circumstances but one of the most basic ones is low or no motivation to learn foreign languages. In this respect it is important to highlight the the necessity of developing non-linguistic university students' motivation to learn foreign languages. Solving this problem is a challenge for university teachers of foreign languages. It has been recognized that teachers are key actors in shaping the learning environment, which is an important factor in forming students' educational motivation (Eccles \& Roeser, 2011; Pintrich, 2004). One of the most important teachers' tasks is to create a learning environment that enhances and sustains students' educational or academic motivation and engages students in learning (Hornstra, Mansfield, van der Veen, Peetsma, \& Volman, 2015).

\section{Motivation}

The term "motivation" has been studied from multiple scientific perspectives, including the psychodynamic, the behaviorist, the humanistic, the goal-setting, the physiological, the phenomenological, the cultural, and the cognitive (Kaplan, 2008; Ryan, 2012; Schunk, 2015). But all of them are characterized by their crossdisciplinary features and touch upon psychology, education, and management. The word "motivation" is widely discussed in scientific studies and it is characterized by the existence of numerous definitions but the authors agree on some key points, mainly that motivation is a deeply psychological phenomenon can generally be defined as the force that governs a person's behavior and drives him/her to be engaged in goaldirected actions (Jenkins \& Demaray, 2015; Schunk, Pintrich \& Meece, 2009; Schunk, 2015).

Self-determination theory proposed and described by Edward L. Deci and Richard M. Ryan (Deci \& Ryan, 2008; Deci, 1975; Deci, 2008; Ryan \& Deci, 2000) is a commonly used theory that touches upon all spheres of human life: education, work, and everyday life. In the frame of this theory, motivation is divided into autonomous (internal or intrinsic) and controlled (external or extrinsic) motivation. According to Deci and Ryan, "autonomous motivation involves behaving with a full sense of volition and choice, whereas controlled motivation involves behaving with the experience of pressure and demand toward specific outcomes that comes from forces perceived to be external to the self" (Deci, 2008). Some researchers suggest considering "amotivation" as a type of motivation (Duchatelet \& Donche, 2019; Ferrari, 1992; Lai, Chui, Wong, \& Chan, 2019; Lee, Lee, Lee, \& Lee, 2019; Ryan \& Deci, 2000; Titrek, Çetin, Kaymak, \& Kaşikçi, 2018; Vallerand et al., 1992). People who are amotivated demonstrate an absence of intent to participate in any activity or do not 
have any goals to achieve (Titrek et al., 2018).

Motivation to learn, or educational (academic) motivation, is of great importance as it is closely interrelated to academic achievements and performance (Comeau, Huta, Lu, \& Swirp, 2019; Duchatelet \& Donche, 2019; Liu \& Chiang, 2019; Titrek et al., 2018). Internal academic motivation is associated with more positive academic performance than external motivation as internal motivation is about personal interest and a desire to do something and external motivation is stimulated from outside (e.g. high marks). However, according to K. Zamfir (Zamfir, 1983), external motivation can be divided into external positive and external negative motivation types. External positive motivatin is based on positive impetus (e.g. high marks). External negative motivation is stimulated by the negative factors (e.g. punishment).

Educational or academic motivation can be defined as a form of cognitive and emotional arousal that influences a learner's academic achievement (Vallerand, 1997). According to K. Hakan and E. Münire (Hakan \& Münire, 2014), academic motivation is an internal state that activates, directs, and maintains learning-related behaviors. Educational motivation is the psychological background of the whole teaching-learning process. In other words, it is an internal impulse to get engaged in an activity. Educational motivation is also always tightly integrated with emotions and emotional state.

Emotions are always responsible for a person's attraction or aversion to one activity or another. A teacher, acting as a kind of a psychologist, has to know how to influence students' emotional states to achieve teaching goals. Lowman believes that teachers are performers and they use their voices, gestures, and movements to elicit and maintain attention and to stimulate students' emotions. Like other performers, teachers must convey a strong sense of presence, using highly focused energy (Lowman, 1984; McCaslin \& Lowman, 2006). In other words, an effective teacher is able to create a motivating classroom environment.

\section{Teaching styles}

Teaching is not a simple job (Pennings \& Hollenstein, 2019), mainly because of the complexity of teacherstudent relationships and the necessity to choose the appropriate role for the teacher in a variety of unique situations. That is why there are a lot of studies dedicated to teacher-student relationships and teacher behavior type and its influence on classroom learning environments, on students' motivation to study, and academic outcomes both in one particular subject and overall studies both at secondary school and at university (Fisher, den Brok, Waldrip, \& Dorman, 2011; Koka, 2013; Pennings \& Hollenstein, 2019; Telli, 2016; Wei, den Brok, \& Zhou, 2009; Zhu, 2013).

There are three main teacher-student interaction styles, and they are based on management styles: authoritarian, democratic, and liberal. However, different numbers of teacher-student interaction styles in related research.

There are various descriptions of teaching styles (teacher-student interaction styles) in modern literature. But in a broad sense, teaching (pedagogical) style can be defined as an identifiable set of classroom behaviors associated with and carried out by the instructor. Grasha (1996) describes teaching style as worked out personal qualities and behaviors that manifest in a teacher's individual way of conducting their classes. Sternberg (1997) says that it is a teacher's preferred way of solving problems, carrying out tasks, and making decisions in the process of teaching, and, besides differing from individual to individual, may sometimes differ between different groups, for example schools.

An authoritarian teaching style characterized by the sovereign authority of a teacher, his/her insistence on high standards, an all-or-nothing mentality, a readiness to punish rather than praise, discipline, and the strict planning of classroom activities. A democratic style can be defined by cooperation in the educational process of decision making, activity planning, educational goal setting and achieving, the development of students' selfdependence and self-government, creativity, and initiative praising. A liberal style is specified by permissiveness, a teacher's policy of noninterference and noninvolvement, the absence of a defined educational activity plan and distinct goals, the teacher's distance from students' lives, interests, and educational needs.

In spite of the number of investigations related to the aforementioned teaching styles and their impact on the educational process, there is an evident lack of studies regarding the influence of pedagogical style on 
students' motivation to learn. The purpose of this research was to identify the characteristics influencing the educational motivation of university students based on the pedagogical style of the teacher (democratic, liberal, or authoritarian). The hypothesis was that students' involvement in the process of forming of cooperative and creative educational activities in classes; being given more freedom in participating in the organizing, problem solving, and decision making process related to educational activities; as well as the opportunity to display the initiative, creativity, and self-government would help in forming students' stable internal motivation to learn.

\section{Materials and methods}

\section{Participants}

We surveyed 230 second-year students of the intramural form of study seeking a baccalaureate degree from Moscow State University of Food Production for the experiment. Among the respondents, there were 143 girls and 87 boys aged 18-20, citizens of the Russian Federation. All the respondents took part in the experiment voluntary but they were not informed about the genuine aim of the research or its details. This was done to assure natural behaviour during the experiment, to obtain the most genuine results possible. The experiment lasted three semesters. All respondents were divided into groups of 15 people. The teacher for the each particular group did not change over the course of the entire experiment.

\section{Methods}

During the experiment, several methods were implemented. First of all, the number of theoretical methods such as analysis and synthesis, induction and deduction, analogy, formalization, modeling, methods of hypotheses and axiomatic, system method, and approach were used during the designing the questionnaires and their interpretations. However, the main methods were methods for the practical implementation of each teaching styles, observation, control, interview, and comparison.

\section{Materials}

In order to examine students' preferences or attitudes related to teaching style, as well as teacher-student interaction style, a questionnaire consisting of four multiple-choice questions (Table 1) was applied.

This questionnaire was designed to group students' preferences into three categories, which were relevant to one of the aforementioned teaching styles. All the " $\mathrm{A}$ " answers reflected the authoritarian style, all the "B" questions the democratic style, and the "C" questions the liberal one.

To score the results, one point should be given for each answer, than all the points for each category "a", "b" and "c" should be summed individually. Students are then assigned to the category with the highest total.

In order to identify the prevailing type of learning motivation and its subtype (namely internal or external (positive/ negative)) the questionnaire was developed on the basis of Academic motivation scale (AMS), developed by R. J. Vallerand (Vallerand et al., 1992). We adopted this method to our needs and interests, namely we shortened the original questionaire and modified the content. Our questinaire was divided into two steps. The first step aimed to reveal the prevailing type of learning motivation to study and supposed that students reported on the items from Table 2 in accordance with their own needs and concerns.

The result should be scored by the following way:

Internal motivation $(\mathrm{IM})=($ the mark of question № $6+$ the mark of question № 7 ) $/ 2$

External positive motivation $(\mathrm{EPM})=($ the mark of question № $1+$ the mark of question № $2+$ the mark of question № 5) / 3

External negative motivation $(\mathrm{ENM})=($ the mark of question № $3+$ the mark of question № 4$) / 2$

The higher mark grade is the stronger motivation is. 


\section{THE INFLUENCE OF THE TEACHING STYLE OF COMMUNICATION ON THE MOTIVATION}

Table 1

The questionnaire revealing students' preferences related to teaching style and educational teacher-student interaction style

\section{Questions}

1 I prefer the teacher who
a. formulates goals and objectives him/herself, makes students follow all his instructions;
b. engages students in the process of goal setting and praises initiative in their their achievements;
c. doesn't set any goals and objects at all.

2 I prefer the teacher who
a. $\quad$ expresses his/her opinions clearly and does not tolerate any objections and disputes;
b. tends to sort out all problems in the form of a dialogue, always takes students' opinion, interests, and needs into account;
c. tries to remain neutral.

3 I prefer the teacher who
a. demands that students follow all the instruction during class and doesn't welcome any kind of student initiative;
b. $\quad$ praises initiative and creativeness;
c. lets students decide themselves what to do.

4 I prefer the teacher who is
a. a leader;
b. a colleague;
c. an observer.

Percentage

Table 2

The method of research of the prevailing type of learning motivation to study in common Why do you study?

\begin{tabular}{|c|c|c|c|c|c|}
\hline & $\begin{array}{c}\text { doesn't } \\
\text { fit } \\
(1) \\
\end{array}$ & $\begin{array}{c}\text { rather doesn't } \\
\text { fit } \\
(2) \\
\end{array}$ & $\begin{array}{c}\text { something in } \\
\text { between } \\
(3)\end{array}$ & $\begin{array}{c}\text { rather } \\
\text { fits } \\
(4)\end{array}$ & $\begin{array}{l}\text { fits } \\
(5)\end{array}$ \\
\hline 1. The desire get a diploma & & & & & \\
\hline 2. Studying is a duty I cannot neglect. & & & & & \\
\hline 3. Because my relatives want me to study & & & & & \\
\hline 4. I do not know exactly & & & & & \\
\hline $\begin{array}{l}\text { 5. I love to study, to solve complex problems } \\
\text { and feel competent. }\end{array}$ & & & & & \\
\hline $\begin{array}{l}\text { 6. Studying gives me the opportunity to } \\
\text { develop my own skills }\end{array}$ & & & & & \\
\hline
\end{tabular}

For the purpose of revealing and estimating the way the students' motivation type changes after "trying on" each of the teacher-student interaction styles (authoritarian, democratic, and liberal) the students were asked to respond to the items in Table 4.

\section{Procedure}

The experiment was divided into three stages and it took us three semesters to complete the study. The aim of the first stage was to investigate the students' preferences related to teaching style, teacher-student interaction style, and the prevailing type of learning motivation to study and learn foreign languages before the main part of the experiment. Two hundred thirty students took part in the interview and answered four multiple choice questions (see Table 1). They were then asked to respond to the items from Table 2 and 3 . After that, the 
incoming English tests were conducted and the educational success of each participant was recorded. It can be stated that this stage was the pre-experiment observation.

The second stage of the study was aimed to investigate how the teacher-student interaction style influenced the nature and type of students' motivation to learn. This was the main stage of the experiment and it lasted three semesters. During the first semester, students studied within the framework of one teaching style, and then over the next two semesters, the teacher changed his/her teaching style. Thus, each of the students was able to "try on" the authoritarian, democratic, and liberal teacher-student interaction style. At Moscow State University of Food Production a point-rating system was applied for students' peformances assessment. We used this system as the main estimation method. During the English classes each semester were assessed such students' activities in class as work during the lesson, involvement in preparing homework, performing creative tasks, and progress tests. The maximum score was 100 points, which equaled $100 \%$. All the results of student performance after each semester were converted into the Academic Grade Average, and this is represented in Table 5. At the end of each semester students reported on the items from Table 4 as well. All the results were scored and recorded for analysis in the last stage of the study.

\section{Table 3}

The method of research of the prevailing type of learning motivation to learn foreign languages

How is it important for you in the English lessons?

\begin{tabular}{|c|c|c|c|c|c|c|}
\hline & & $\begin{array}{c}\text { not } \\
\text { important } \\
(1)\end{array}$ & $\begin{array}{c}\text { in a little } \\
\text { measure } \\
(2)\end{array}$ & $\begin{array}{c}\text { in a medium } \\
\text { measure } \\
(3)\end{array}$ & $\begin{array}{l}\text { in a great } \\
\text { enough } \\
\text { measure } \\
(4)\end{array}$ & $\begin{array}{c}\text { in a great } \\
\text { measure } \\
(5)\end{array}$ \\
\hline 1 & High marks & & & & & \\
\hline 2 & $\begin{array}{l}\text { The desire speak English fluently, because } \\
\text { it is necessary for an educated person } \\
\text { nowadays }\end{array}$ & & & & & \\
\hline 3 & $\begin{array}{l}\text { The desire to escape from teacher's and } \\
\text { group mates' criticism }\end{array}$ & & & & & \\
\hline 4 & The desire to escape from punishment & & & & & \\
\hline 5 & The desire to be the best student & & & & & \\
\hline 6 & $\begin{array}{l}\text { The satisfaction from the process of } \\
\text { learning the subject }\end{array}$ & & & & & \\
\hline 7 & $\begin{array}{l}\text { The possibility to develop one's own skills } \\
\text { in this subject }\end{array}$ & & & & & \\
\hline
\end{tabular}

\section{Table 4}

The method of research of the prevailing type of learning motivation after implementing one of the educational teacher-student interaction style (the authoritarian, democratic and liberal)

I studied English during this semester because

\begin{tabular}{|c|c|c|c|c|c|c|}
\hline & & $\begin{array}{c}\text { doesn't } \\
\text { fit } \\
(1)\end{array}$ & $\begin{array}{c}\text { rather doesn't } \\
\text { fit } \\
\text { (2) }\end{array}$ & $\begin{array}{l}\text { something in } \\
\text { between } \\
\text { (3) }\end{array}$ & $\begin{array}{l}\text { rather } \\
\text { fits } \\
\text { (4) }\end{array}$ & $\begin{array}{l}\text { fits } \\
(5)\end{array}$ \\
\hline 1 & I wanted to get high marks. & & & & & \\
\hline 2 & $\begin{array}{l}\text { I wanted to speak English fluently } \\
\text { is necessary for an educated person } \\
\text { nowadays. }\end{array}$ & & & & & \\
\hline 3 & $\begin{array}{l}\text { of the desire to escape from teacher's and } \\
\text { group mates' criticism. }\end{array}$ & & & & & \\
\hline 4 & of the desire to escape from punishment. & & & & & \\
\hline 5 & $\begin{array}{l}\text { of the desire to be the best student in the } \\
\text { group. }\end{array}$ & & & & & \\
\hline 6 & $\begin{array}{l}\text { of the satisfaction from the process of } \\
\text { learning the subject. }\end{array}$ & & & & & \\
\hline 7 & $\begin{array}{l}\text { of the possibility of developing my own } \\
\text { skills in this subject. }\end{array}$ & & & & & \\
\hline
\end{tabular}


In the last stage of the study, the output testing of student performance was implemented and all the results from the previous stage were compared and analyzed (Ivanova, Shlenskaya, Khorokhorina, \& Kurbakova, 2019). Furthermore, the results of the questionnaire revealing students' preferences related to teaching style and teacher-student interaction style made before the experiment (see Table 5) were compared to the results of the main study. The aim was to identify if the teacher-student interaction style could change the preferences of students to teaching style and, as a result, encourage better academic performance.

\section{Results and discussion}

The study made it possible to obtain data related to the influence of the educational teacher-student interaction style on the motivation of students to learn.

Table 5

Results of the questionnaire revealing students' preferences related to teaching style and educational teacher-student interaction style

\begin{tabular}{|c|c|c|c|c|}
\hline & Question & $\begin{array}{c}\text { Quantity of chosen } \\
\text { answers "A" }\end{array}$ & $\begin{array}{l}\text { Quantity of chosen } \\
\text { answers "B" }\end{array}$ & $\begin{array}{c}\text { Quantity of chosen } \\
\text { answers "C" }\end{array}$ \\
\hline 1 & $\begin{array}{l}\text { I prefer the teacher who } \\
\text { a. formulates goals and objectives himself, makes students } \\
\text { follow all his instructions; } \\
\text { b. engages students in the process of goal setting and } \\
\text { praises initiative in their achievements; } \\
\text { c. doesn't set any goals and objects at all. }\end{array}$ & 131 & 74 & 25 \\
\hline 2 & $\begin{array}{l}\text { I prefer the teacher who } \\
\text { a. expresses his/her opinions clearly and does not tolerate } \\
\text { any objections and disputes; } \\
\text { b. tends to sort out all problems in the form of a dialogue, } \\
\text { always takes students' opinion, interests and needs in } \\
\text { account; } \\
\text { c. tries to remain neutral. }\end{array}$ & 99 & 78 & 53 \\
\hline 3 & $\begin{array}{l}\text { I prefer the teacher who } \\
\text { a. demands students follow all the instruction during the } \\
\text { class and doesn't welcome any kind of initiative; } \\
\text { b. praises initiative and creativeness; } \\
\text { c. lets students decide themselves what to do. }\end{array}$ & 138 & 48 & 44 \\
\hline 4 & $\begin{array}{l}\text { I prefer the teacher who is } \\
\text { a. a leader; } \\
\text { b. a colleague; } \\
\text { c. an observer. }\end{array}$ & 120 & 73 & 37 \\
\hline & Percentage & $50 \%$ & $29.75 \%$ & $17.25 \%$ \\
\hline
\end{tabular}

Table 5 shows that the most preferable teacher-student interaction style among students was the authoritarian style. Answers "A" were chosen by $53 \%$ of the students. Based on these results, we came to the conclusion that the majority of the respondents tended to be led and controlled by the teacher and preferred following their teachers' instructions instead of taking the initiative and being pro-active and self-governed. Next, $29.75 \%$ of the respondents chose the democratic teacher-student interaction style. This is a collaborative way of educational activity and the students who choose this specific way of teacher-student interaction are striving to be a fullfledged participant in the educational process. Their desire is to demonstrate creativeness and show initiative. They are ready to take on educational decisions and be responsible for the results. Finally, the least number of students selected the liberal style. Ony $17.25 \%$ of students surveyed didn't mind if the teacher was neutral or unconcerned about the educational process and students' interests, needs, or success in learning. These students are mainly amotivated. They don't want to study at all, that is why they show full indifference to the teacher-student relationships and educational process in general.

The findings showed that before the experiment 120 students (52.2\%) reported intrinsic motivation, 82 students (35.6\%) had extrinsic motivation, and only 28 people (12.2\%) were amotivated.

The findings also showed that before the study only 51 students (22.2\%) came in with intrinsic motivation, 142 
people (61.7\%) with extrinsic motivation, and 37 respondent (16.1\%) were amotivated.

The Academic Grade Average based on the incoming test of the respondents before the study worked out to $71 \%$ equaling an educational mark of " 4 ". This is because 57 respondents $(24.8 \%)$ got the mark " 5 ", 126 respondents $(54,8 \%)$ got the mark “ 4 ", 43 students (18.7 \%) got the mark “ 3 ", and just 4 people (1.7 \%) got the mark " 2 ".

The main stage of the study showed that authoritarian and democratic teacher-student interaction styles had a more positive effect on students' academic performance, while the liberal style had a negative effect (see Table 6).

Table 6

The Academic Grade Average recordings

\begin{tabular}{ccc}
\hline The authoritarian teaching style & The democratic teaching style & The liberal teaching style \\
\hline $\begin{array}{c}87 \% \\
\text { equals " } 5 \text { " }\end{array}$ & $\begin{array}{c}75 \% \\
\text { equal “ } 4 \text { " }\end{array}$ & $\begin{array}{c}62 \% \\
\text { equals " } 3 \text { " }\end{array}$ \\
\hline
\end{tabular}

A comparative analysis of the results encouraged us to conclude that students' motivation to learn English was higher in those periods when the authoritarian and democratic teacher-student interaction style were implemented. Furthermore, the democratic style encouraged predominantly external positive motivation, while the authoritarian style significantly activated internal motivation. It is should be brought into focus that the liberal teacher-student interaction style took a heavy toll on the students' motivation, as it activated predominantly external negative motivation or made students amotivated (see Table 7).

Table 7

Overall performance of the teacher-student interaction style influence on the formation of the prevailing type of learning motivation

Authoritarian teacher-student interaction style

\begin{tabular}{cccc}
\hline Internal motivation & External positive motivation & External negative motivation & Amotivation \\
\hline 135 & 51 & 40 & 4 \\
$58.7 \%$ & $22.2 \%$ & $17.4 \%$ & $1.7 \%$ \\
\hline
\end{tabular}

Democratic teacher-student interaction style

\begin{tabular}{cccc}
\hline Internal motivation & External positive motivation & External negative motivation & Amotivation \\
\hline 73 & 101 & 51 & 5 \\
$31.7 \%$ & $43.9 \%$ & $22.2 \%$ & $2.2 \%$ \\
\hline
\end{tabular}

Liberal teacher-student interaction style

\begin{tabular}{cccc}
\hline Internal motivation & External positive motivation & External negative motivation & Amotivation \\
\hline 10 & 22 & 167 & 31 \\
$4 \%$ & $10 \%$ & $72.6 \%$ & $13.4 \%$ \\
\hline
\end{tabular}

The comparison of the results revealing students' preferences related to teaching style and teacher-student interaction style obtained before the experiment (see Table 5) and the results obtained after the main study showed that $99 \%$ of the respondents who preferred the authoritarian teacher-student interaction style had better academic performance while being taught with an authoritarian teacher-student interaction style. Only $1 \%$ of the respondents who preferred the authoritarian teacher-student interaction style demonstrated better academic performance while being taught within the frame of democratic teacher-student interaction style. Sixty-six percent of the respondents who preferred the democratic teacher-student interaction style confirmed their choice while $33.4 \%$ went with the authoritarian teacher-student interaction style. And $29.4 \%$ of those who chose the liberal teacher-student interaction style didn't change their opinion while $70.6 \%$ had better marks when being taught with the authoritarian or democratic teacher-student interaction style. This fact helped us come to the conclusion that in most cases the respondents' preferences to teacher-student interaction style didn't change. Our respondents were young adults and by the time they entered university they understood which types of relationships with teacher were more productive or effective for them. However, in some cases the respondents' preferences to one teacher-student interaction style or another could change. 
The results of conducted study allow us to state that the formation of student's motivation to learn foreign languages is interconnected and depends on teacher-student interaction style. By using a given style of teacherstudent interaction, the teacher can manipulate not only the students' academic performance but also their emotional state, and as a result their desire to become a full-fledged educational participant or just an observer (Ivanova et al., 2019). However, we should state that our hypothesis was not confirmed and the most positive effect on students' academic performances and motivation type to learn foreign languages was shown to be the authoritarian teacher-student interaction, not the democratic one.

The experiment demonstrated that most students consciously preferred the authoritarian teacher-student interaction style (see Table 5) and this was evidenced in the main part of our study (see Tables 6 and 7). A greater number of students want to be lead and strictly instructed during the educational process. They do not want to take the initiative, be creative, and be responsible for the educational process and the result. The interaction "teacher-leader/student" creates more productive conditions to encourage Russian students' internal motivation to learn. However, it is worthwhile to state that there was one group of students that demonstrated positive academic performances and formed internal motivation after having learned under the democratic style for one semester. We should also pay attention to that fact that the liberal teaching style has an adverse effect on students' academic performance and the students' motivation was essentially degraded or fully absent. When the teacher plays the role of teacher-observer or consultant and is not concerned about the educational process or lets students decide for themselves what to do or not to do, the students lose their motivation.

\section{Conclusions}

At a time when the importance of knowing of foreign languages is extremely high and the demand for specialists who are proficient in a foreign language is increasing, we are facing the problem of low motivation to learn a foreign language among non-linguistic majors. We proposed that the type of teacher-student interaction style could influence student motivation and this study was designed to explore this question and find out how teacher-student interaction style (the authoritarian, democratic, or liberal) influenced the type of motivation (internal, external positive, external negative or amotivation). After conducting our study, we came to the conclusion that the choice of teaching style plays a great role in students' motivation, leading to internal and positive and negative external motivation, as well as amotivation. The results of the experiment clearly demonstrate that both authoritarian and democratic teacher-student interaction styles can have a positive influence on students' educational behaviour and academic performance while the implementation of the liberal teacher-student interaction style led to motivational decreases or to amotivation thus resulting in a decrease in academic performance. At the same time, we can assume than the combining of teaching styles according to students' needs, interests, and preferences can bring about more prolific educational results. Furthermore, a comparison of the results of the questionnaire revealing students' preferences related to teacher-student interaction style obtained before the experiment and the results obtained after the main study led us to suggest that in order to increase the level of motivation to learn foreign languages and to create the most comfortable learning environment for each particular student group, the interview or questionnaire on students' preferences related to teacher-student interaction style should be applied and the results use to help teachers organize their educational strategic plans.

\section{References}

Comeau, G., Huta, V., Lu, Y., \& Swirp, M. (2019). The Motivation for Learning Music (MLM) questionnaire: Assessing children's and adolescents' autonomous motivation for learning a musical instrument. Motivation and Emotion, 1-14. https://doi.org/10.1007/s11031-019-09769-7

Debyser F. (1983). Guide pédagogique pour le professeur de français langue étrangère (Teacher's guide to French as a foreign language). Paris, France: Hachette.

Deci, E. L., \& Ryan, R. M. (2008). Self-determination theory: A macrotheory of human motivation,development, and health. Canadian Psychology, 182-185. https://doi.org/10.1037/a0012801

Deci, E. L. (1975). Intrinsic motivation. New York, NY: Plenum Press. https://doi.org/1 0.1 007/978-1-4613-4446-9 
Deci, E. L., \& Ryan, R. M. (2008). Facilitating optimal motivation and psychological well-being across life's domains. Canadian Psychology, 49(1), 14-23. https://doi.org/10.1037/0708-5591.49.1.14

Duchatelet, D., \& Donche, V. (2019). Fostering self-efficacy and self-regulation in higher education: A matter of autonomy support or academic motivation? Higher Education Research \& Development, 38(4), 733-747. https://doi.org/10.1080 /07294360.2019.1581143

Eccles, J. S., \& Roeser, R. W. (2011). Schools as developmental contexts during adolescence. Journal of Research on Adolescence, 21(1), 225-241. https://doi.org/10.1111/j.1532-7795.2010.00725.x

Ferrari, J. R. (1992). Psychometric validation of two Procrastination inventories for adults: Arousal and avoidance measures. Journal of Psychopathology and Behavioral Assessment, 14(2), 97-110. https://doi.org/10.1007/BF00965170

Fisher, D., den Brok, P., Waldrip, B., \& Dorman, J. (2011). Interpersonal behaviour styles of primary education teachers during science lessons. Learning Environments Research, 14(3), 187-204. https://doi.org/10.1007/s10984-011-9093-z

Grasha, A. F. (1996). Teaching withstyle : A practical guide to enhancing learning byunderstanding teaching and learning syles. Pittsburgh, PA: Alliance Publishers. https://doi.org/10.1017/CBO9781107415324.004

Hakan, K., \& Münire, E. (2014). Academic Motivation: Gender, domain and grade differences. Procedia - Social and Behavioral Sciences, 143, 708-715. https://doi.org/10.1016/j.sbspro.2014.07.469

Hornstra, L., Mansfield, C., van der Veen, I., Peetsma, T., \& Volman, M. (2015). Motivational teacher strategies: The role of beliefs and contextual factors. Learning Environments Research, 18(3), 363-392. https://doi.org/10.1007/s10984015-9189-y

Ivanova, M., Shlenskaya, N., Khorokhorina, G., \& Kurbakova, S. (2019). The influence of the pedagogical style of communication on the motivation of students to learn. INTED2019 Proceedings (pp. 9819-9826).

Jenkins, L. N., \& Demaray, M. K. (2015). An investigation of relations among academic enablers and reading outcomes. Psychology in the Schools, 52(4), 379-389. https://doi.org/10.1002/pits.21830

Kaplan, A. (2008). Achievement motivation. In E. Anderman \& L. H. Anderman (Ed.), Psychology of Classroom Learning (Vol. 1, pp. 13-17). Detroit, MI: Macmillan Reference.

Koka, A. (2013). The relationships between perceived teaching behaviors and motivation in Physical Education: A one-year longitudinal study. Scandinavian Journal of Educational Research, 57(1), 33-53. https://doi.org/10.1080/00313831.20 11.621213

Lai, A. H. Y., Chui, C. H.-K., Wong, K.-Y., \& Chan, C. L. W. (2019). Academic motivations of Yi youths in China: Classmate support and ethnic identity. The Journal of Educational Research, 112(4), 550-563. https://doi.org/10.1080/00220671. 2019.1602820

Lee, M. Y., Lee, M. K., Lee, M. J., \& Lee, S. M. (2019). Academic burnout profiles and motivation styles among Korean high school students. Japanese Psychological Research, jpr.12251. https://doi.org/10.1111/jpr.12251

Liu, R., \& Chiang, Y.-L. (2019). Who is more motivated to learn? The roles of family background and teacher-student interaction in motivating student learning. The Journal of Chinese Sociology, 6(1), 6. https://doi.org/10.1186/s40711019-0095-z

Lowman, J. (1984). Mastering the techniques of teaching. San Francisco, California: Jossey-Bass.

McCaslin, W. J., \& Lowman, J. (2006). Mastering the Techniques of Teaching. Teaching Sociology, 12(4), 494. https://doi. org/10.2307/1318070

Pennings, H. J. M., \& Hollenstein, T. (2019). Teacher-student interactions and teacher interpersonal styles: A state space grid analysis. The Journal of Experimental Education, 1-25. https://doi.org/10.1080/00220973.2019.1578724

Pintrich, P. R. (2004). A conceptual framework for assessing motivation and self-regulated learning in college students. Educational Psychology Review, 16(4), 385-407. https://doi.org/10.1007/s10648-004-0006-x

Ryan, R. M. (2012). Motivation and the organization of human behavior: Three reasons for the reemergence of a field. The Oxford Handbook of Human Motivation. New York, NY: Oxford University Press. https://doi. org/10.1093/oxfordhb/9780195399820.013.0001

Schunk, D. H. (2015). Learning theories: An educational perspective. Boston, MA: Pearson. https://doi.org/10.1017/ CBO9781107415324.004

Schunk, D. H., Pintrich, P. R. \& Meece, J. L. (2009). Motivation in education. Upper Saddle River, N.J.: Pearson Education.

Sternberg, R. J. (1997). Thinking styles. New York, NY: Cambridge University Press.

Telli, S. (2016). Students' perceptions of teachers' interpersonal behaviour across four different school subjects: Control is good but affiliation is better. Teachers and Teaching, 22(6), 729-744. https://doi.org/10.1080/1354 0602.2016.1158961

Tikhonova, E., \& Raitskaya, L. (2018). An overview of trends and challenges in higher education on the worldwide research agenda. Journal of Language and Education, 4(4), 4-7. https://doi.org/10.17323/2411-7390-2018-4-4-4-7

Titrek, O., Çetin, C., Kaymak, E., \& Kaşikçi, M. M. (2018). Academic motivation and academic self-efficacy of prospective 
teachers. Journal of Education and Training Studies, 6(11a), 77-82. https://doi.org/10.11114/jets.v6i11a.3803

Vallerand, R. J. (1997). Toward a hierarchical model of intrinsic and extrinsic motivation. In M. P. Zanna (Ed.), Advances in Experimental Social Psychology. New York, NY: Academic Press.

Vallerand, Robert J., Pelletier, L. G., Blais, M. R., Briere, N. M., Senecal, C., \& Vallieres, E. F. (1992). The Academic Motivation Scale: A measure of intrinsic, extrinsic, and amotivation in education. Educational and Psychological Measurement, 52(4), 1003-1017. https://doi.org/10.1177/0013164492052004025

Wei, M., den Brok, P., \& Zhou, Y. (2009). Teacher interpersonal behaviour and student achievement in English as a foreign language classrooms in China. Learning Environments Research, 12(3), 157-174. https://doi. org/10.1007/s10984-009-9059-6

Zamfir K. (1983). Udovletvorennost' trudom [Work satisfaction]. Moscaw, Russia: Poliizdat.

Zhu, C. (2013). Students' and teachers' thinking styles and preferred teacher interpersonal behavior. The Journal of Educational Research, 106(5), 399-407. https://doi.org/10.1080/00220671.2012.736431 